\title{
A Rare Presentation of Pigmented Spindle Cell Squamous Cell Carcinoma (SCC) of Conjunctiva - A Case Report
}

\author{
Dr. Ashutosh Patel ${ }^{1}$, Dr. Renuka Barki ${ }^{2}$
}

\begin{abstract}
Conjunctival SCC comprise Ocular Surface Squamous Cell Neoplasias along with other ocular adenexal SCC. SCC is the considered to be most common malignancy of the conjunctiva. This case report highlights a rare case of pigmented spindle cell squamous cell carcinoma-in-situ conjunctiva in HIV patient. A 55 year male patient presented to ophthaldepartement complaining of growth over conjunctiva on nasal side in right eye since 2 months which was associated with mild pain. On examination Conjunctiva showed a fleshy brownish mass over nasal side of right conjunctiva measuring 1.7 x1.4 c.m. in size with minimal vascularization. Conjunctival growth was excised \& was sent for histopathological examination. Histopathology report suggested the mass to be " pigmented spindle cell squamous cell carcinoma-in-situ-Conjunctiva”. This case suggests that HIV infection is animportant risk factor for Ocular surface squamous neoplasia.
\end{abstract}

Keywords: Conjunctiva, Pigmented Spindle cell carcinoma,(OSSN) ocular surface squamous neoplasia

\section{Introduction}

Conjunctival SCC comprise Ocular Surface Squamous Cell Neoplasias(OSSN) along with corneal SCC. SCC is the most common malignancy of the conjunctiva. Risk factors for the disease are exposure to sun (specifically occupational), exposure to UVB, and light-colored skin. Other risk factors include radiation, smoking, HPV, immunosuppression, arsenic, and exposure to polycyclic hydrocarbons.

Conjunctival SCC is often asymptomatic at first, but it can present with the presence of a growth over conjunctiva, red eye, pain, itching, burning, photophobia, diplopia, and decreased vision. Spread of conjunctival SCC can occur to other body tissues, the most common site of spread being the regional lymph nodes. Diagnosis is often made by biopsy, as well as CT (in the case of invasive SCC).

\section{Objective}

To highlight a rare case of pigmentedspindle cell squamous cell carcinoma-in-situ conjunctiva in HIV patient.

\section{Materials \& Methods}

Case report

A 55 year male patient presented to ophthal department complaining of growth over conjunctiva on nasal side in right eye since 2 months which was insidious in onset \& gradually progressed to present size over the time. Growth was associated with pain in the right eye with foreign body sensation. Pain was pricking in nature, intermittent type\& was associated with redness of eye.

No h/o visual problem /headache/itching.

No history of any ocular trauma/ eye discharge.

Patient gave the history of RTA 5 months back. Patient had multiple deep abrasions \& was treated at local hospital. Three months after the accident on routine investigations patient was diagnosed as $\mathrm{HIV}(+)$ case \& was started on HAART therapy.

On examination, his visual acuity of RE was 6/9, no improvent with pin hole.

LE was 6/6

Ocular motility - normal ocular movement of BE.

Adnexa - Normal in both eyes.

Conjunctiva showed a fleshy brownish mass over nasal side of right conjunctiva measuring $1.7 \times 1.4$ c.m. in size with minimal vascularization..

Cornea, was clear in botheyes

AC was normal in depth and contents.

Pupils were brisk and reactive.

Lens revealed grade 1-2 nuclear sclerosis in both eyes.

Fundus examination was within normal limitis in both eyes.

\section{Surgical biopsy}

Conjunctival growth was excised \& was sent for histopathological examination. Histopathology report suggested the mass to be " pigmented spindle cell squamous cell carcinoma-in-situ-Conjunctiva". Patient was referred to surgery \& dermatology department to rule out presence of any other intra-abdominal or cutaneous malignancies.

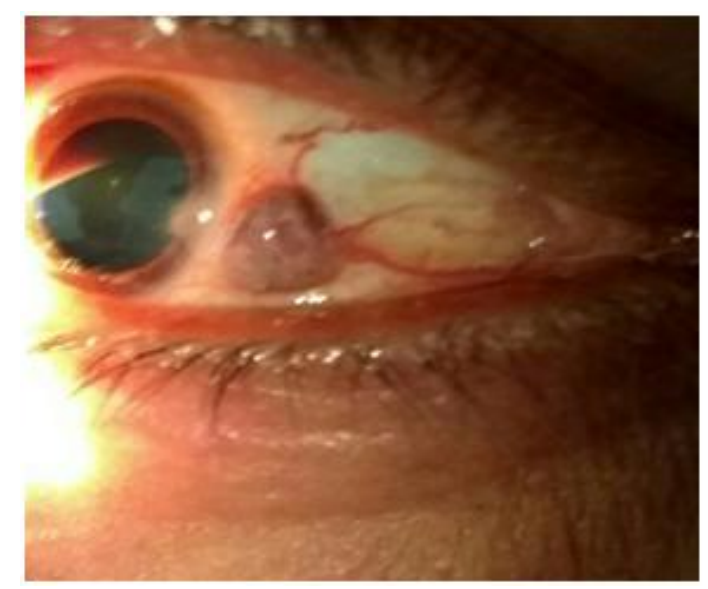

Figure 1: Conjunctival mass noted on nasal Conjunctiva 


\section{International Journal of Science and Research (IJSR) \\ ISSN (Online): 2319-7064}

Index Copernicus Value (2015): 78.96 | Impact Factor (2015): 6.391

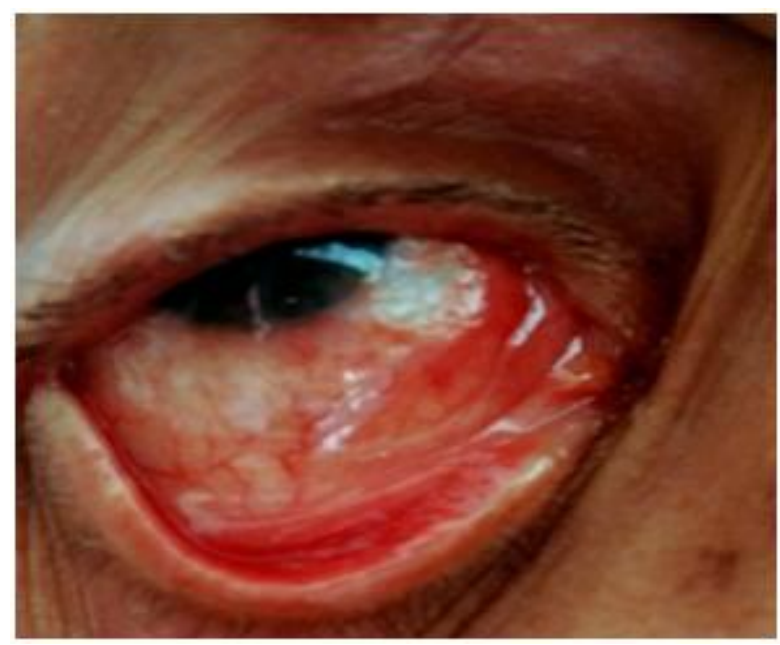

Figure 2: Conjunctival mass resected surgically at time of presentation

\section{Discussion}

The conjunctiva is a mucous membrane with a surface composed of nonkeratinizing stratified squamous epithelium intermixed with goblet and Langerhans cells. Tumors of the conjunctiva and cornea comprise a large and varied spectrum of conditions. These tumors are grouped into two major categories of congenital and acquired lesions. The acquired lesions are further subdivided based on origin of the mass into surface epithelial, melanocytic, vascular, fibrous, neural, histiocytic, myxoid, myogenic, lipomatous, lymphoid, leukemic, metastatic and secondary tumors. Ocular surface tumors include a variety of neoplasms originating from squamous epithelium, melanocytes, and lymphocytic resident cells of the conjunctival stroma. The clinical spectrum of OSSN includes benign lesions like squamous papilloma, precancerous lesions as actinic keratosis, carcinoma in situ and invasive squamous carcinoma.

\section{Carcinoma in Situ (CIS)}

It is a full thickness replacement of epithelium by frankly malignant cells: Epithelial basement membrane is intact, with no invasion into substantia propria. Clinically, it presents as an opalescent papillary masses at limbus with minimal leukoplakia. Cells show loss of polarity and anaplasia. Spindle and epidermoid variants are detected on histopathology. Spindle cell and mucoepidermoid variants represent a more aggressive tumor with early invasion and frequent recurrences

Spindle cell carcinoma is rare and locally more aggressive variant of squamous cell carcinoma of conjunctiva. Cervantes and associates in their large series of 287 cases of squamous cell carcinoma have reported only two cases of spindle cell squamous cell carcinoma. Spindle cell carcinoma/Sarcomatoid carcinoma is characterized by a biphasic pattern of squamous cell carcinoma with a generally much larger component of malignant spindle cells (divergent differentiation) reminiscent of a sarcoma. The squamous component may be scanty or even inapparent on light microscopy). In the latter circumstance, immunehistochemical and electron microscopic evidence of squamous differentiation is required for diagnosis. By immunohistochemistry, sarcomatous component is characteristically vimentin positive, may be positive for actin and desmin, and often shows only limited or absent staining for traditional epithelial markers such as cytokeratin or epithelial membrane antigen. In such challenging cases, immunostaining for p63 is another useful marker for the identification of epithelial differentiation. Spindle cell carcinoma on ultrastructural studies displays features of epithelial differentiation in spindle cells, such as desmosomes and tonofilaments. Spindle cell carcinoma is much more likely to extend through the sclera and cornea into the interior of the globe. Differential diagnoses of spindle cell carcinoma call for exclusion of malignant spindle cell lesions such as fibrosarcoma, leiomyosarcoma, malignant fibrous histiocytoma and amelanotic malignant melanoma. However in conjunctiva sarcomas are even rarer and spindle cell carcinoma is still more likely.

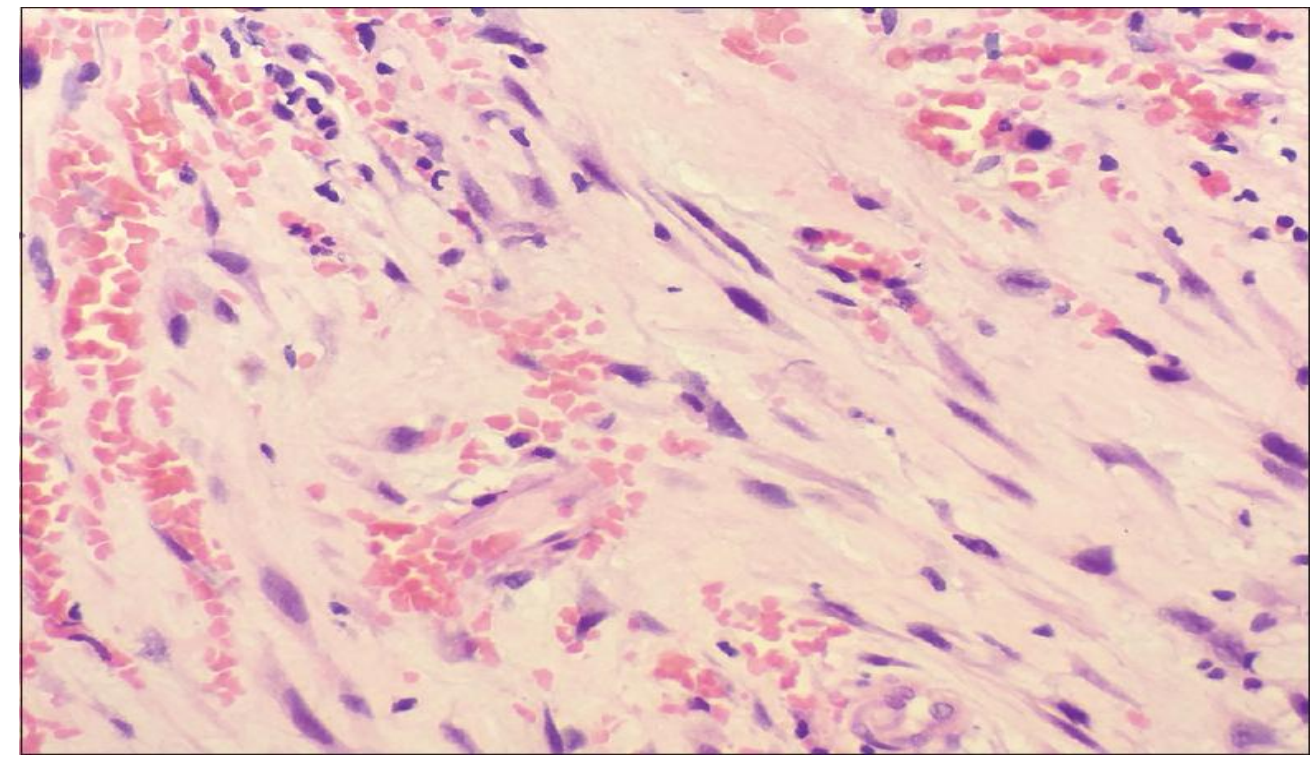

Figure: Spindle cell Squamous cell carcinoma of conjunctiva.

Volume 6 Issue 7, July 2017 www.ijsr.net 


\section{International Journal of Science and Research (IJSR) \\ ISSN (Online): 2319-7064}

Index Copernicus Value (2015): 78.96 | Impact Factor (2015): 6.391

\section{Conclusion}

An increase in the incidence of OSSN, since the HIV pandemic, has suggested that HIV infection increases the risk for OSSN. HIV infection is now established as a risk factor for the development of squamous cell neoplasia of the conjunctiva. OSSN occurring in HIV patients are more aggressive and invasive requiring enucleation or even exenteration. Spindle cell carcinoma is an aggressive variant with a tendency to metastasize. These are generally managed surgically with wider margins. Histopathology is the gold standard in the diagnoses of various grades and types of OSSN, and gives a fair understanding of disease prognosis. Conjunctival impression cytology could be a diagnostic aid or to confirm flat corneal-limbal lesions.

Future studies are needed to understand the pathogenesis of OSSN and the role of various carcinogens specifically HPV and HIV in varied manifestations of the disease process and their role in prognosis of disease. Further work is required in the re-diagnoses of OSSN \& mode of its management.

\section{References}

[1] Lee, G.A. and Hirst, L.W. Incidence of ocular surface epithelial dysplasia in metropolitan Brisbane. A 10-year survey. Arch. Ophthalmol.1992; 110: 525-527.

[2] Meha, M. and Fay, A. Squamous cell carcinoma of the eyelid and conjunctiva. Int. Ophthalmol. Clin.2009; 49: 111-121.

[3] McKelvre, P.A., Daniell, M., McNab, A., Loughnan, M., and Santamaria, J.D. Squamous cell carcinoma of the conjunctiva: a series of 26 cases. Br. J. Ophthalmol. 2002; 86: 168-173.

[4] Seregard, S. and Kock, E. Squamous Spindle Cell Carcinoma of the Conjunctiva-Fatal outcome of a pterygium-like lesion. Acta Ophthalmol. Scand.1995; 73: 464-466.

[5] Iliff WJ, Marback R, Green WR. Invasive squamous cell carcinoma of the conjunctiva. Arch Ophthalmol1975;93:119-22.

[6] Shields JA, Shields CL, Gunduz K, et al. Intraocular invasion of conjunctival squamous cell carcinoma in five patients. The 1998 Pan American Lecture. Ophthal Plastic Reconstruct Surg1999;15:153-60.

[7] Blodi FC. Squamous cell carcinoma of the conjunctiva. Doc Ophthalmol1973;34:93-108.

[8] Yang J, Foster CS. Squamous cell carcinoma of the conjunctiva. IntOphthalmolClin1997;37:73-85.

[9] TuncM, Char DH, Crawford B, et al. Intraepithelial and invasive squamous cell carcinoma of the conjunctiva: analysis of 60 cases. Br J Ophthalmol1999;83:98-103.

[10] MidenaE, DegliAngeli C, Valenti M, et al. Treatment of conjunctival squamous cell carcinoma with topical 5fluorouracil. Br J Ophthalmol2000;84:268-72.

[11] TabriziSN, McCurrach FE, Drewe RH, et al. Human papillomavirus in corneal and conjunctival carcinoma. Aust NZ J Ophthalmol1997;25:211-15.

[12] Tole D, McKelvie PA, Daniell M. The reliability of impression cytology for the diagnosis of ocular surface squamous neoplasia employing the biopore membrane. Br J Ophthalmol2001;85:154-8.
[13] Cohen B.H., Green W.R., Iliff N.T., Taxy J.B., Schwab L.T., de la Cruz Z. Spindle cell carcinoma of the conjunctiva. Arch. Ophthalmol. 1980;98:1809-1813.

[14] Shields, J.A., Shields, C.L., Luminais, S., Eagle, R.C. Jr. Differentiation of pigmented conjunctival squamous cell carcinoma from melanoma. Ophthalmic Surg Lasers Imaging. 2003;34:406-408.

[15]Kremer, I., Sandbank, J., Weinberger, D. et al, Pigmented epithelial tumours of the conjunctiva. Br J Ophthalmol. 1992;76:294-296.

[16] Gichuhi, S., Sagoo, M.S., Weiss, H.A., Burton, M.J. Epidemiology of ocular surface squamous neoplasia in Africa. Tropical Med. Int. Health. 2013;18:1424-1443.

[17] Guech-Ongey, M., Engels, E.A., Goedert, J.J., Biggar, R.J., Mbulaiteye, S.M. Elevated risk for squamous cell carcinoma of the conjunctiva among adults with AIDS in the United States. Int. J. Cancer. 2008;122:2590 2593.

[18] Ateenyi-Agaba, C., Franceschi, S., Wabwire-Mangen, F., Arslan, A., Othieno, E., Binta-Kahwa, J., van Doorn, L.J., Kleter, B., Quint, W., Weiderpass, E. Human papillomavirus infection and squamous cell carcinoma of the conjunctiva. Br. J. Cancer. 2010;102:262-267.

[19] Ramberg, I., Heegaard, S., Prause, J.U., Sjö, N.C., Toft, P.B. Squamous cell dysplasia and carcinoma of the conjunctiva. A nationwide, retrospective, epidemiological study of Danish patients. Acta Ophthalmol.2015;93:663-666.

[20] Gichuhi, S., Irlam, J.H. Interventions for squamous cell carcinoma of the conjunctiva in HIV-infected individuals. Cochrane Database Syst. Rev.2013;28:CD005643.

[21] Yousef, Y.A., Finger, P.T. Squamous carcinoma and dysplasia of the conjunctiva and cornea: an analysis of 101 cases. Ophthalmology. 2012;119:233-240. 